\title{
CHANGES IN PHOSPHORUS FRACTIONS ON AN ACIDIC SOIL INDUCED BY PHOSPHORUS FERTILIZER, ORGANIC MATTER AND LIME
}

\author{
A.Hartono', P.L.G. Vlek' ${ }^{2}$ A. Moawad ${ }^{2}$ and A. Rachim' \\ ${ }^{1}$ Laboratory of Soil Chemistry and Fertility, Department of Soll Sciences, \\ Faculty of Agriculture, Bogor Agricultural University \\ 2 Institute of Agriculture in the Tropics of Goettingen University
}

\begin{abstract}
One month of incubation experiment was implemented to evaluate the changes of phosphorus fraction in inorganic $\mathrm{P}(\mathrm{Pi})$ and organic $\mathrm{P}(\mathrm{Po})$ induced by phosphorus fertilizer $\left(\mathrm{KH}_{2} \mathrm{PO}_{4}\right)$, cow manure ( manure) and $\mathrm{CaCO}_{3}$ (lime). A $0.5 \mathrm{~kg}$ oven-dried weight of arable layers of Latosol from Darmaga, Bogor was used in this study. The rates of manure were 0, 12.5 and 25 tha, lime were $0,1,3$ times the $\mathrm{CaCO}_{3}$ equivalent required to neutralize exchangeable aluminum amounting to $0,3.01,8.03$ tha respectively and the rates of phosphorus fertilizer in $\mathrm{KH}_{2} \mathrm{PO}_{4}$ were 0,40 and $80 \mathrm{~kg}$ $\mathrm{P} / \mathrm{ha}$. All treatments increased resin-Pi (biologically available $\mathrm{P}$ ). Application of phosphorus fertilizer also increased $\mathrm{NaHCO}_{3}-\mathrm{Pi}$ which is also included as biologically available $\mathrm{P}$, while manure and lime only tended to increase this fraction. Phosphorus fertilizer and manure application were able to enhance $\mathrm{NaOH}-\mathrm{Pi}$ (moderately resistant $P$ related to AI-P and Fe-P) but lime did not affect it. Phosphorus fertilizer, manure and lime increased $\mathrm{HCl}-\mathrm{Pi}$ (moderately resistant $\mathbf{P}$ related to $\mathrm{Ca}-\mathrm{P}$ ). The changes of $\mathrm{NaHCO}_{3}-\mathrm{Pi}$ to resin-Pi and $\mathrm{P}$ immobilization by microorganism, which was indicated by the increase of $\mathrm{NaHCO}_{3}-\mathrm{Po}$ (readily mineralizable), can be attributed to the decrease of $\mathrm{NaHCO}_{3}$ $\mathrm{Pi}$. The increase of NaOH-Pi by phosphorus fertilizer and manure indicated that the complexation of $P$ fixation sites by $\mathrm{PO}_{4}{ }^{-}$and organic acids likely had occurred.
\end{abstract}

Key words : Phosphorus fraction, phosphorus fertilizer, manure, lime, resin-Pi, $\mathrm{NaHCO}_{3}-\mathrm{Pi}$, $\mathrm{NaHCO}-\mathrm{Po}, \mathrm{NaOH}-\mathrm{Pi}, \mathrm{HCl}-\mathrm{Pi}$

\section{INTRODUCTION}

The decrease of $P$ sorption of an acidic soil derived from Darmaga due to the application of phosphorus fertilizer, manure and lime was reported by Hartono (2000). One possible mechanism for this results, the $\mathrm{PO}_{4}-$ released by phosphorus fertilizer and manure was sorbed by sites of P sorption (Reddy et al., 1980; lyamuremye et al., 1996). While the declining of exchangeable $\mathrm{Al}$ was one of the reasons to explain the decrease of $P$ sorption by lime (Frossard et al., 1995).

Chemical fixation of $P$ in soil is due to the ability of soils materials, such as allophanic, clay mineral, and $\mathrm{Al}$ or $\mathrm{Fe}$ oxides and hydrous oxides, to strongly sorb $\mathrm{PO}_{4}{ }^{-}$ion (Parfitt, 1978). Fixation sites in an acidic soil as occurred in the soil from Darmaga could be caused by Al or $\mathrm{Fe}$ oxides and hydrous oxides or soluble $\mathrm{Al}$ or Fe. The latter will react quickly with soluble $P$ (Lee et al., 1990).

As consequences, the decreased $P$ sorption in acid soil from Darmaga due to complexation of fixation sites will change the distribution of $P$ fractions. The objective of this study was to measure the changes of $P$ fractions induced by phosphorus fertilizer, manure and lime application to an acidic soil from Darmaga Bogor. 


\section{MATERIALS AND METHODS}

An incubation experiment was conducted in the greenhouse of Department of Soil Sciences, Faculty of Agriculture, Bogor Agricultural University. Surface samples of arable layers of Latosol from Darmaga, Bogor was used in this study. The soil samples were collected from the practical field which has been applied phosphorus fertilization for thirteen years without organic matter and lime addition and the soil is always planted maize once in a year (Sutandi and Nugroho, 1998). The soil sample from the field were screened through $2 \mathrm{~mm}$ sieves and air-dried. Cow manure residue was obtained from the Animal Husbandry Faculty of Bogor Agricultural University. This manure residue was air-dried, ground and sieved using a $1 \mathrm{~mm}$ sieve. $\mathrm{CaCO}_{3}$ was as liming material and $\mathrm{KH}_{2} \mathrm{PO}_{4}$ was used as phosphorus fertilizer.

Soil samples $(0.5 \mathrm{~kg}$ oven-dried) were put into polybag pots and mixed with the combination of manure, $\mathrm{CaCO}_{3}$ and $\mathrm{P}$ fertilizer. Manure was added at rates of 0 (control), 12.5 tha and 25 tha. $\mathrm{CaCO}_{3}$ as lime source was added at the rates of 0,1 , and 3 times the $\mathrm{CaCO}_{3}$ equivalent required to neutralize exchangeable aluminum amounting to $0,3.01,9.03$ tha respectively and $P$ fertilizer in $\mathrm{KH}_{2} \mathrm{PO}_{4}$ was added ranging from 0,40 and $80 \mathrm{~kg}$. P/ha. Deionized water was added to the treated soil to bring the soil moisture to mount $66 \%$ of water holding capacity.

All pots were incubated in the greenhouse for one month. The sampling was scheduled at the end of the incubation period. The water content of the pots were maintained every two days gravimetrically. After the period of incubation, the soil samples were air-dried before analyses. The experiment was completely randomized design and was analysed by standard ANOVA procedures with means separation by Tukey's procedures. Prior to the incubation experiment the initial chemical and physical properties of the soil, manure and lime were determined (Table 1).

Fractionation of $P$ was performed in four subsamples incubated soil by the method of Tiessen and Moir (1993), (Table 2).

The $0.5 \mathrm{~g}$ soil was weighted and put into $50-\mathrm{ml}$ centrifuge tube, then $0.4 \mathrm{~g}$ resin (Dowex $1-\times 80$ 50 mesh) oversaturated with bicarbonate in nylon bags and $30 \mathrm{ml}$ of deionized water were added and after that shaken overnight (16 h).
The bag containing resin was removed and soil was washed off into the tube. Bag containing resin was placed in a clean $50-\mathrm{ml}$ tube and added $20 \mathrm{ml} 0.5 \mathrm{M} \mathrm{HCl}$. It was set aside for 1 hour to allow gas out and then capped and shaken overnight (16 $h$ ). $P$ inorganic (resin $P i)$ was determined.

The soil suspension was centrifuged at 10000 rpm for 5 minutes. Water was decanted through a millipore filter. Water was discarded and the soil was washed off filter back into the tube with a little $0.5 \mathrm{M} \mathrm{NaHCO}_{3}(\mathrm{pH}$ 8.5) and added more $0.5 \mathrm{M} \mathrm{NaHCO}_{3}$ solution to bring solution volume to $30 \mathrm{ml}$ and shaken suspension overnight (16 h). Soil suspension was centrifuged at $10000 \mathrm{rpm}$ for 5 minutes. $\mathrm{NaHCO}_{3}$ extract was decanted through a millipore filter into a clean vial. $P$ inorganic $\left(\mathrm{NaHCO}_{3}-\mathrm{Pi}\right)$ and total $\mathrm{P}$ on bicarbonate extract were determined. $P$ organic $\left(\mathrm{NaHCO}_{3}-\mathrm{Po}\right)$ was obtained by subtracting total $P$ with $\mathrm{NaHCO}_{3}$ Pi.

Any soil was washed back off filter into the tube using a little $0.1 \mathrm{M} \mathrm{NaOH}$ and added more 0.1 $M \mathrm{NaOH}$ solution to bring solution volume to 30 $\mathrm{ml}$ and shaken suspension overnight $(16 \mathrm{~h})$. Soil suspension was centrifuged at $10000 \mathrm{rpm}$ for 5 minutes. $\mathrm{NaOH}$ extract was decanted through a millipore filter into a clean vial. $P$ inorganic on $\mathrm{NaOH}$ extract $(\mathrm{NaOH}-\mathrm{Pi})$ was determined.

Any soil was washed back off filter into the tube using a little $1 \mathrm{M} \mathrm{HCl}$ and added more $1 \mathrm{M} \mathrm{HCl}$ solution to bring solution volume to $30 \mathrm{ml}$ and shaken suspension overnight $(16 \mathrm{~h})$. Soil suspension was centrifuged at $10000 \mathrm{rpm}$ for 5 minutes. $\mathrm{HCl}$ extract was decanted through a clean vial. $P$ inorganic in $\mathrm{HCl}$ extract $(\mathrm{HCl}-\mathrm{Pi})$ was determined. $P$ was measured by the method of Murphy-Riley (1982) using Hitachi UV 2000 Spectrophotometer with wave length $712 \mathrm{~nm}$. All analyses were conducted in the Center for Soil and Agroclimate Research, Bogor.

\section{RESULTS AND DISCUSSION}

\section{Biologically available $P$ (Resin-Pi and $\mathrm{NaHCO}$ - $\mathrm{Pi}$ and $\left.\mathrm{P}_{0}\right)$}

Resin $\mathrm{Pi}$ is readily available for plant uptake, and $0.5 \mathrm{M} \mathrm{NaHCO}_{3}-\mathrm{Pi}$ is highly related to $\mathrm{P}$ uptake by plants (Schmidt et al., 1996). The former represents soil solution $P$, soluble phosphate originating from calcium phosphates 
Table 1. Initial soil, manure and lime analyses

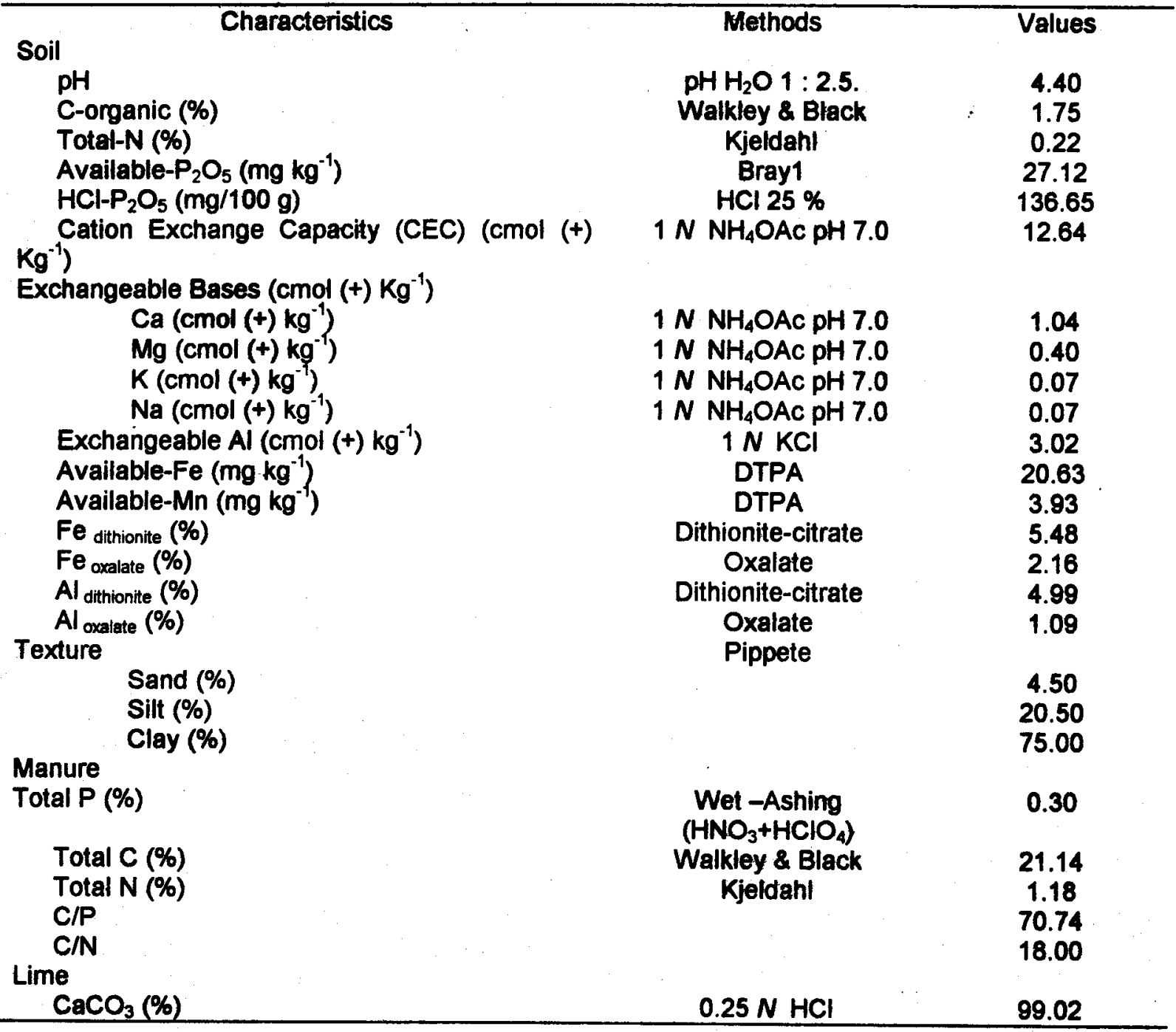

Table 2. Characterization of sequential soil-P extraction

\begin{tabular}{|c|c|}
\hline $\begin{array}{l}\text { P-extractant } \\
\text { Biologically available } \mathrm{P} \text { : } \\
\text { Resin } \mathrm{P} \text { inorganic }(\mathrm{Pi}) \text { in } 0.1 \mathrm{M} \\
\mathrm{HCl} \\
0.5 \mathrm{M} \mathrm{NaHCO}_{3}-\mathrm{Pinorganic}(\mathrm{Pi}) \\
\text { and } \mathrm{P} \text { organic }(\mathrm{PO}) \\
\text { Moderately resistant : } \\
0.1 \mathrm{M} \text { NaOH-Pinorganic }(\mathrm{Pi}) \\
1 \mathrm{M} \mathrm{HCl-Pinorganic}(\mathrm{Pi})\end{array}$ & $\begin{array}{l}\text { Extract } P \text { inorganic that is readily available to plants } \\
\text { Extract strongly related to } P \text { uptake by plants and } \\
\text { microbial activity } \\
\text { More strongly held by chemisorption to } \mathrm{Fe} \text { and } \mathrm{Al} \\
\text { components of soil surface } \\
\text { Extract mainly } \mathrm{Ca}-\mathrm{P} \text { of low solubility }\end{array}$ \\
\hline
\end{tabular}

and loosely adsorbed $P$ inorganic on ther surface of sesquioxides or carbonates (Tiessen and Moir, 1993).
Increasing rates of phosphorus fertilizer, manure and lime added to the soil increased the resin $\mathrm{Pi}$ significantly (Table 3 ). The increase was comparable although it was found little bit smaller on the application of lime. 
Table 3. Effect of phosphorus fertilizer, manure and lime on the resin-Pi and $\mathrm{NaHCO}_{3}-\mathrm{Pi}$ mean values after one month incubation

\begin{tabular}{|c|c|c|}
\hline Treatment & Resin-Pi & $\mathrm{NaHCO}_{3}-\mathrm{Pi}$ \\
\hline $\begin{array}{c}\text { Rate of } P(\mathrm{~kg} / \mathrm{ha}) \\
0 \\
40 \\
80\end{array}$ & $\begin{array}{l}3.20 \mathrm{c} \\
6.06 \mathrm{~b} \\
8.62 \mathrm{a}\end{array}$ & $\begin{array}{c}28.67 \mathrm{~b} \\
30.38 \mathrm{ab} \\
32.30 \mathrm{a}\end{array}$ \\
\hline $\begin{array}{c}\text { Rate of manure (t/ha) } \\
0 \\
12.5 \\
25 \\
\text { Rate of lime (t/ha) }\end{array}$ & $\begin{array}{l}3.93 \mathrm{c} \\
5.89 \mathrm{~b} \\
8.05 \mathrm{a}\end{array}$ & $\begin{array}{l}30.60 \mathrm{~b} \\
27.81 \mathrm{c} \\
32.94 \mathrm{a}\end{array}$ \\
\hline $\begin{array}{c}0 \\
3.01 \\
9.03 \\
\end{array}$ & $\begin{array}{l}4.20 \mathrm{c} \\
5.81 \mathrm{~b} \\
7.86 \mathrm{a}\end{array}$ & $\begin{array}{l}29.73 \mathrm{~b} \\
32.16 \mathrm{a} \\
29.46 \mathrm{~b}\end{array}$ \\
\hline
\end{tabular}

Mean values followed by the same letter within a column are not significantly different

(Tukey's test, $\alpha=0.05$ )

Schmidt et al. (1996) and lyamuremye et al. (1996) found similar result with the application of phosphorus fertilizer and manure respectively and the former considered that resin-Pi as a sink to excess phosphorus.

The contrary result was mentioned by lyamuremye et al. (1996) that lime did not affect resin $\mathrm{Pi}$ but it agrees with Taylor and Gurney (1965) that lime increased resin-Pi which can be attributed to the decrease of exchangeable Al precipitated by $\mathrm{OH}$.

The increasing rates of phosphorus fertilizer increased $\mathrm{NaHCO}_{3}-\mathrm{Pi}$ significantly. Manure with rate of 12.5 tha caused a significant decrease but on the contrary with the application of $25 \mathrm{t} / \mathrm{ha}$. The decrease of $\mathrm{NaHCO}_{3}-\mathrm{Pi}$ when treated by $12.5 \mathrm{t}$ manure/ha may be because of the changes of $\mathrm{NaHCO}_{3}-$ $\mathrm{Pi}$ to resin $\mathrm{Pi}$ (Tiessen and Moir, 1993). A sink to excess phosphorus was explanation to the increase of resin-Pi and $\mathrm{NaHCO}_{3}-\mathrm{Pi}$ because of the application of $25 \mathrm{t}$ manure/ha.

Lime at the rate of 3.01 tha was able to increase $\mathrm{NaHCO}_{3}-\mathrm{Pi}$ but at higher dosage did not show different effect. The changes of $\mathrm{NaHCO}_{3}-\mathrm{Pi}$ to the resin $\mathrm{Pi}$ can be attributed to this phenomena. Beside that the immobilization of $\mathrm{NaHCO}_{3}-\mathrm{Pi}$ by microorganism because of favorable changes of $\mathrm{pH}$ is also possible (Pavan and Carneiro, 1995). It is also confirmed by the result of $\mathrm{NaHCO}_{3}-\mathrm{P}_{0}$ obtained by this research (Table 4) that pool of $\mathrm{NaHCO}_{3-}$ Po increased when $\mathrm{NaHCO}_{3}$-Pi decreased.
It agrees with lyamuremye et al. (1996) on the application of manure. The contrary result was found on the application of lime which resulted in little or no increase in the amount of $\mathrm{NaHCO}_{3}-\mathrm{Pi}$. In other investigation the application of phosphorus fertilizer and manure significantly increased $\mathrm{NaHCO}_{3}-\mathrm{Pi}$ and $\mathrm{Po}$ (Reddy et al., 1999).

\section{Moderately resistant $P(\mathrm{NaOH}-\mathrm{Pi}$ and $\mathrm{HCl}-\mathrm{Pi})$}

The $\mathrm{NaOH}$ extractant removes $P$ which is less related to $P$ plant uptake (Enwezor, 1977) and is associated with amorphous and crystalline $A$ I and Fe phosphates. To that respect, $\mathrm{NaOH}-\mathrm{Pi}$ is more strongly held by chemisorption to $\mathrm{Fe}$ and $\mathrm{Al}$ components of soil surface (Tiessen and Moir, 1993). It is shown that application of phosphorus fertilizer and manure was able to increase the $\mathrm{NaOH}-\mathrm{Pi}$ significantly while lime did not have any effect on the NaOH-Pi (Table 5).

Pavan and Androcioli (1995) reported that application of compost and mulch was able to promote $\mathrm{NaOH}-\mathrm{Pi}$. While Schmidt et al. (1996) found that $\mathrm{NaOH}-\mathrm{Pi}$ fraction also represents a sink for excess $P$ fertilization and significantly increased across $P$ treatments.

The increase of this fraction observed in this acidic soil amended by phosphorus fertilizer and manure was likely as a result of $\mathrm{PO}_{4}{ }^{-}$ released from phosphorus fertilizer and manure. Unlike phosphorus fertilizer and manure, lime did not add any soluble inorganic 
Table 4. Effect of phosphorus fertilizer, manure and lime on the $\mathrm{NaHCO}_{3}-\mathrm{Po}$ mean values after one month incubation

\begin{tabular}{|c|c|}
\hline Treatment & $\begin{array}{c}\mathrm{NaHCO}_{3}-\mathrm{PO} \\
\left(\mathrm{mg} \mathrm{kg}^{-1}\right)\end{array}$ \\
\hline $\begin{array}{c}\text { Rate of } P(\mathrm{~kg} / \mathrm{ha}) \\
0 \\
40 \\
80\end{array}$ & $\begin{array}{c}28.22 \mathrm{~b} \\
30.81 \mathrm{a} \\
29.75 \mathrm{ab}\end{array}$ \\
\hline $\begin{array}{c}\text { Rate of manure (t/ha) } \\
0 \\
12.5 \\
25\end{array}$ & $\begin{array}{l}24.22 \mathrm{~b} \\
32.76 \mathrm{a} \\
31.80 \mathrm{a}\end{array}$ \\
\hline $\begin{array}{c}\text { Rate of lime (t/ha) } \\
0 \\
3.01 \\
9.03\end{array}$ & $\begin{array}{l}28.01 \mathrm{~b} \\
28.33 \mathrm{~b} \\
32.44 \mathrm{a}\end{array}$ \\
\hline
\end{tabular}

Mean values followed by the same letter within a column are not significantly different (Tukey's test, $\alpha=0.05$ )

Table 5. Effect of phosphorus fertilizer, manure and lime on the $\mathrm{NaOH}-\mathrm{Pi}$ and $\mathrm{HCl}-\mathrm{Pi}$ mean values after one month incubation

\begin{tabular}{|c|c|c|}
\hline \multirow[t]{2}{*}{ Treatment } & $\mathrm{NaOH}-\mathrm{Pi}$ & $\mathrm{HCl}-\mathrm{Pi}$ \\
\hline & \multicolumn{2}{|c|}{$\mathrm{mg} \mathrm{kg}^{-1}$. } \\
\hline Rate of $P(\mathrm{~kg} / \mathrm{ha})$ & & \\
\hline $\begin{array}{l}0 \\
40 \\
80\end{array}$ & $\begin{array}{l}445.80 \mathrm{C} \\
477.73 \mathrm{~b} \\
514.80 \mathrm{a}\end{array}$ & $\begin{array}{l}15.70 \mathrm{~b} \\
15.80 \mathrm{~b} \\
21.71 \mathrm{a}\end{array}$ \\
\hline Rate of manure (t/ha) & & \\
\hline $\begin{array}{c}0 \\
12.5 \\
25\end{array}$ & $\begin{array}{l}460.99 \mathrm{c} \\
481.45 \mathrm{~b} \\
495.89 \mathrm{a}\end{array}$ & $\begin{array}{l}15.17 \mathrm{c} \\
18.44 \mathrm{~b} \\
18.60 \mathrm{a}\end{array}$ \\
\hline Rate of lime (t/ha) & & \\
\hline $\begin{array}{l}0 \\
3.01 \\
9.03\end{array}$ & $\begin{array}{l}478.95 \mathrm{a} \\
480.39 \mathrm{a} \\
478.95 \mathrm{a}\end{array}$ & $\begin{array}{l}16.87 \mathrm{~b} \\
17.48 \mathrm{~b} \\
18.87 \mathrm{a}\end{array}$ \\
\hline
\end{tabular}

Mean values followed by the same letter within a column are not significantly different (Tukey's test, $\alpha=0.05$ )

$P$ or organic $P$ so there is no phosphate precipitated by $\mathrm{Fe}$ and $\mathrm{Al}$ as shown by this experiment.

Furthermore, it is appeared that phosphorus fertilizer, manure and lime tended to enhance HCl-Pi (Table 4). Similar result was reported by Pavan and Androcioli (1995) in the application of compost and mulch. The absence of major changes in $\mathrm{HCl}-\mathrm{Pi}$ is understandable because the soil is acid which would favor formation of $\mathrm{Al}$ and $\mathrm{Fe} P$ inorganic compounds over $\mathrm{Ca}$ products. The $\mathrm{HCl}-\mathrm{Pi}$ fraction is associated mainly with insoluble Ca-P compounds such as hydroxyapatite (Tiessen and Moir, 1993). CONCLUSIONS

Resin- $\mathrm{Pi}$ and $\mathrm{HCl}-\mathrm{Pi}$ increased when treated with phosphorus fertilizer, manure and lime. The similar result was found for $\mathrm{NaHCO}_{3}-\mathrm{Pi}$, but only small increase recorded in lime and manure treatments.

The $P$ immobilization by microorganism can be attributed to the decreased $\mathrm{NaHCO}_{3}-\mathrm{Pi}$ which indicated by the increase of $\mathrm{NaHCO}_{3}-\mathrm{Po}$ pool. 
The decrease of $\mathrm{NaHCO}_{3}-\mathrm{Pi}$ can also be attributed to the changes of this fraction to resin-Pi.

Phosphorus fertilizer and manure containing a lot of total $P(0.3 \%)$ also increased $\mathrm{NaOH}-\mathrm{Pi}$ largely react with $\mathrm{Al}$ and $\mathrm{Fe}$ (chemisorbed $\mathrm{P}$ inorganic) but lime (inorganic amendment) did not affect this $P$ fraction.

The increase of NaOH-Pi by phosphorus fertilizer and manure indicated that the complexation of surface sites of $P$ sorption by $\mathrm{PO}_{4}{ }^{-}$and organic acids likely had occurred.

\section{ACKNOWLEDGEMENTS}

The authors would like to express great thanks to:

- DAAD-GTZ for the scholarship given, Dr Diethard Mai, Dr Uirich Loffler and all officials in CeTSAF (Tropenzentrum) Göttingen .

- Prof. Dr Ir Edi Gurnardi and staffs in Post Graduate Program IPB-Bogor,

- Center for Soil and Agroclimate Research (Pusat Penelitian Tanah dan Agroklimat), Bogor, Indonesia and staffs, and all of my colleagues at the Department of Soil Sciences, IPB, Bogor for all inputs and discussion.

\section{REFERENCES}

Enwezor, W. O. 1977. Soil testing for phosphorus in some Nigerian Soils: I. Comparison of methods of determining available phosphorus in soils of southeastern Nigeria. Soil. Sci. 123:48-53.

Frossard, E., M. Brossard, M. J. Hadley and A. Metherell. 1995. Reaction controlling the cycling of $P$ in soils. $P p$. 54:107137. In $\mathrm{H}$. Tiessen (ed.). Phosphorus in the global environtment: Transfer, cycles, and management. John Wiley \& Sons. Chicester, New York, Brisbane, Toronto, Singapore.
Hartono, A. 2000. Pengaruh pupuk fosfor, bahan organik, dan kapur terhadap perubahan erapan $P$ pada tanah masam Latosol Darmaga. Jurnal IImiah Pertanian Gakuryoku. VI:73-78.

lyamuremye, F., R. P. Dick and J. Baham. 996. Organic amendments and phosphorus dynamics: II. Distribution of soil phosphorus fractions. Soil Sci. 161: 436-443.

Lee, D., X. G. Han, C. F. Jordan. 1990. Soil phosphorus fraction, aluminum, and water retention as affected by microbial activity in an ultisol. Plant Soil 121:125-136.

Murphy, J., and J. P. Riley. 1962. A modified single solution for the determination of phosphate in natural waters. Anal. Chim. Acta. 27:31-36.

Parfitt, R. L. 1978. Anion adsorption by soils and soil materials. Adv. Agron. 30:150.

Pavan, M.A., and F. A. Androcioli. 1995. Fracionamento de fosforo em un experimento de manejo da fertilidade do solo para producao de cafe no noroeste de Parana. Arquivos de Biologia e Tecnologia. 38:157-165.

Pavan, M.A., and A. L. Carneiro. 1995. Utilization of a fractionation technique to characterize phosphorus status in soil incubated with leucaena residues. Arquivos de Biologia e Tecnologia. 38: 375-386.

Reddy K. R., M. R. Overcash, R. Khaleel, and P. W. Westerman. 1980. Phosphorus adsorption-desorption characteristics of two soils utilized for disposal of animal wastes. J. Environt. Qual. 9:86-92

Reddy, D. D., A. Sabba Pao and P. N. Takkar. 1999. Effects of repeated manure and fertilizer phosphorus additions on soil phosphorus dynamics under a soybean-wheat rotation. Biol. Fert. of Soil. 28:150-155. 
Schmidt, J. P., S. W. Buol and E. J. Kamprath. 1996. Soil dynamics during seventeen years of continuous cultivation: fractionation analyses. Soil Sci. Soc. Am. J. 60:1168-1172.

Sutandi, A. and B. Nugroho (1998): Practical Guide for Fertilizer and Fertility (In Indonesia). Dept. of Soil Science, Faculty of Agriculture, Bogor Agricultural University.
Taylor, A. W. and E. L. Gurney. 1965. The effect of lime on the phosphate potential and resin extractable phosphate in five acid soils. Soil Sci. Soc. Amer. Proc. 29:482-483.

Tiessen, $H$. and J. $O$. Moir. 1993. Characterisation of available $P$ by sequential extraction. In Soil Sampling and Methods of Analysis. M. R. Carter, (ed.). Can. Soc. of Soil Sci. Lewis Publ., pp. 75-88. 